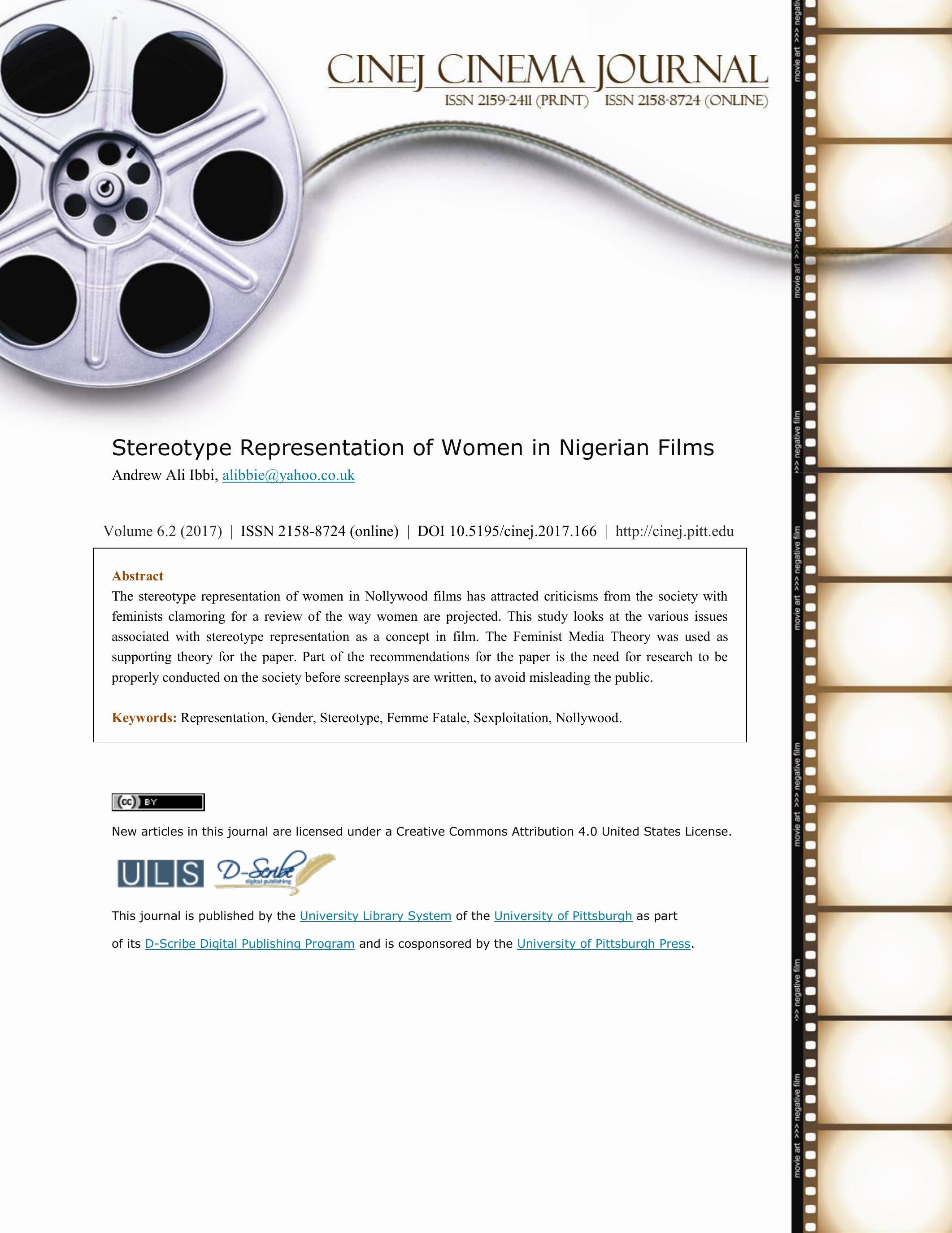




\section{Stereotype Representation of Women in Nigerian Films}

\section{Andrew Ali Ibbi}

\section{Introduction}

The issue of gender has been one that has attracted so many commentaries in the media. For time now, rights groups and feminists have decried the level of negative representation of women in the mass media. McDougall (2012: 52) defines representation as the sum of various micro parts, stating that it relates to the broader theories of collective identity, cultivation and ideology. Buckingham (2003: 57) explained that the notion of representation is one of the founding principles of media education. "The media do not offer us a transparent window on the world but a mediated version of the world. They don't just present reality, they re-present it." This implies that what the media projects to the audience stands the possibility of being accepted by the audience as a true reflection of reality. To this point, women groups have taken to various media platforms to protest the negative representation of women in the media especially film, television and advertisements.

In many cultures around Africa, a clear line is often drawn to separate the men from the women. This has been defined and enshrined in the unwritten laws of the land and despite the advancement in civilization, this difference is still very much visible. Nigeria being an Africa country still has this practice going on. According to Dutt (2014: 3), since the women's liberation movement in the 1960s, their roles in social, cultural, political and economic life has drastically changed and progressed for the better, seemingly giving women an equal footing to men in most aspects of life. But the male dominance of the film industry, like many other industries around the world, is still evident in the 21st century. Amobi (2013) brings this scenario to Nigeria by stating that even after four world conferences on women, Nigerian women continue to experience marginalization in every sphere of human endeavor. 
The Nigerian film industry has grown to be the largest in Africa and one of the three largest in the world. Amobi (2013) further expressed concerns that in spite of the unprecedented growth and success of the industry, the content of these movies rather than reflect messages that correct societal ills appear to reinforce gender disparity in their portrayal of women. The nature of societies within Nigeria are structured along patriarchal lines where the girl child is seen as lesser than a man hence, there are certain societal roles that they are forbidden from participating in. This line of thought has reflected in the types of roles that women are given in movies in the country.

Nigeria is a multi-ethnic country with more than 100 tribes each with a distinct language and culture from the other. Nigeria is the third most ethnically and linguistically diverse country in the world, after New Guinea and Indonesia (Blench, 2003). If there is anything that these different cultures have in common, it is the issue of marginalization of women. Cultures within the country share the common notion that the woman must be under the control of the man at all time. As the protest against the negative representation of women continue to dominate the agenda of feminists the world over, there is hope that this trend will take a different dimension especially with the coming of women as directors and producers in the Nigerian film industry.

Downing and Husband (2005) quoted Winant (1994) as saying the concepts of race, ethnicity, feminism and their likes are essentially metaphors for institutionalized social relationships that combine processes of exploitation and domination, on the one hand, with processes of subjection and representation, that is, with struggles over meaning and identity, on the other. Having said this, it is worthy to note that in Nigeria, representation along the lines of these concepts will continue to assume a more productive dimension if Nigerian movie makers will inject funds into research on the various ethnic groups in Nigeria. Similarly, the idea that a woman should always play second fiddle or are symbols of sexploitation can be watered down in the face of more sensitive issues that will foster national unity and development. 


\section{Theoretical Framework}

\section{Feminist Media Theory}

According to McDougall (2012), Feminist Media Theory is a complex range of approaches. Central to this range of approaches is the questioning of powerful gender norms that are reinforced to a greater or lesser extent in media and the relationship between media representation of gender and inequalities in broader social life. At the center of this theory is the concept of feminism. McDougall (2012: 178), stated that the word is often misunderstood as an extreme, militant politics. "Feminism is nothing more outrageous than the belief that we should oppose media texts that represent women as in-equal to men or as mere unthinking objects for male scrutiny." Scholars like Humm (1992: 403) explained that historically, people and movements have been called feminists when they recognized the connections between social inequalities, deprivations and oppressions and gender differences. To McQuail (2010), the concept of feminism is a political as well as a cultural project.

According to many feminist scholars, the mass media have the power to influence people's thinking and for that reason, certain stereotype representation of women have the tendencies of encouraging some of the stereotype representations of women to thrive in the society. McQuail (2010: 123) outlined the following which form the basis for the argument in the feminist media theory:

- Media have marginalized women in the public sphere.

- Media purvey stereotypes of feminity and masculinity.

- Production of content of media are gendered.

- Female perspective offers alternative criteria of equal.

- The personal is political.

- Media offer positive and supportive as well as negative role models. 
From the above, when taking a closer look at representation of gender in the media, the women have suffered from stereotype representation in Nigerian movies, ranging from prostitutes, to witches, to gold diggers, to husband killers and so on. Considering the fact that the media offer positive and supportive as well as negative role models, the society stands the risk of having its youth copying how the media are portraying the women.

\section{Conceptual Model}



Fig 1: Conceptual framework of female stereotype representation in Nigerian films Source: (Ibbi, 2016). 


\section{Gender Structure of the Nigerian Society}

Nigeria, a country in West Africa has a population of about 178.5 million people as at 2014. This population is scattered across 36 states and a federal capital territory, with the populace belonging to more than 100 ethnic groups. When it comes to the family structure of cultures in Nigeria, the Man is the head of the family. Allanana (2013) explained that in Nigeria, it is observed that the womanhood is reduced to a mere infidel and a second-class citizen, hence, there is the commonality of general belief system that the best place for women is in the 'Kitchen'. This is a notion that is common among all the ethnic groups in the country. According to Aina (1998), from time immemorial, the Nigerian society has been a patriarchy society. While defining patriarchy, Asiyanbola (2005) said: It is a system of social stratification and differentiation on the basis of sex, which provides material advantages to males while simultaneously placing severe constraints on the roles and activities of females. In many Nigerian cultures, the woman is restricted from participating in some activities that are seen as strictly for men. For instance, participating in a wrestling contest or going on a hunting expedition. Allanana (2013) defined patriarchy as a system of social stratification and differentiation on the basis of sex, which provides material advantages to males while simultaneously placing severe constraints on the roles and activities of females. Asiyanbola (2005) explained this further: "Males are classed as having the following qualities: strength, vigor, virile/powerful courage, self-confidence and the ability to meet the outside world i.e. animal and human intruders head on and deal with it effectively. These qualities were reflected in the kinds of work that men engaged in. Men were responsible for much of what was thought of as 'heavy' labour."

This mentality denied many women in colonial and early post-colonial Nigeria the opportunity of benefitting from western education. Many parents had formed the opinion that the 
woman will always end up in a man's house and must do the bidding of her husband. Even with the constraint of playing second fiddle, the Nigerian woman on close examination has been a strong force in the development of the family system in the country. Allanana (2013) explained that women constitute about half of the population of the Nigerian state and are known to play vital roles as mothers, producers, managers, community developers/organizers etc. Their contribution to the social and economic development of societies is also more than half as compared to that of men by virtue of their dual roles in the productive and reproductive spheres.

\section{According to Allanana (2013: 115)}

Women are therefore discriminated upon from, in most cases, acquiring formal education, mistreated and perpetually kept as house-help; the average Nigerian woman is seen as an available object for prostitution, forced marriage, street hawking, instrument of wide-range trafficking and a misfit in the society. Thus, the purported irrelevance associated with the status of women in society has merely reduced an average woman to an inferior commodity.

Though there has been a notable change in the social structures of many families across the country in the new millennium, the patriarchy mentality is still consciously or unconsciously displayed especially by the males in the society. Consequently, this has to some extent affected the psyche of some Nigerian women as they reluctantly accept what the society has put in place since time immemorial so as not to either be seen as deviants or to avoid being marooned by the larger society.

\section{What Is Representation?}

According to Hall (1997), representation is the production of meaning through language. The Oxford English Dictionary defines representation in two contexts:

1. To describe or depict something, to call it up in the mind by description or portrayal or imagination; to place a likeness of it before us in our mind or in the senses

2. To symbolize, stand for, to be a specimen of or to substitute for. For example, the red cap worn by elders in Igbo land is a representation of their titles in society. 
However, while looking at it from the angle of film studies, representation can be seen as an attempt by the media to re-present some aspects of societal reality. Goodwill, Good and Godfrey (2007) aligned to this thought by saying "Film is a representational system that communicates concepts and feelings in such a way as to enable interpretation of their meanings." A film may invite its audience to understand a preferred reading of it yet a viewer's social positioning may influence their reading of a film.

Stewart and Kowaltzke (2007) explain that a "media representation is a depiction, a likeness or a constructed image. A representation can be a single image, a sequence of images or a whole program, written words, spoken words or song lyrics." It is obvious that the concept has a broader meaning than the simple definition given by the Oxford English Dictionary. Hall (1997) emphasized that representation is an essential part of the process by which meaning is produced and exchanged between members of a culture.

Just like any other work of art, an element of representation is capable of drawing several interpretations. It therefore means that sometimes the intent of the movie maker is not meant to suggest a misrepresentation of a phenomenon but because the two step flow theory is active, the concept will be subjected to various interpretations by opinion leaders which could in the long run result in controversies. Representations invite audiences to understand them and agree with them in certain preferred ways. However, depending on the experiences of the audience, a single representation in a movie is bound to receive different interpretations.

According to Stewart and Kowaltzke (2007), representations have a mode of address. This implies that Hidden behind the apparent naturalness of the representation will be some assumptions about who you are. For example, if girls are portrayed as only belonging to the kitchen and can only play second fiddle to men, the possibility of the men feeling important in the house is high. 
To them, the movie is addressing them as the lords over the women. In the same vein, some weak minded women may see themselves as being unfortunate in life thereby giving up on dreams they might have been building.

An aspect of representation that is the crux of this paper is stereotype. This is seen as a judgmental type of representation. Stewart and Kowaltzke (2007) see stereotype as "A stereotype is an oversimplified, clichéd image, repeated so many times that it seems to have established a pattern. It is a highly judgmental type of representation." Stereotypes are an extreme form of representation. They are constructed by a process of selection. Certain aspects are focused on and then exaggerated. This is in line with the views of Branston and Stafford (2006:241), "stereotypes are widely circulated ideas or assumptions about particular groups." At the same time, an evaluation is made and the audience is invited to make a judgement, which is often based on prejudice. Repetition establishes stereotypes and over time allows them to appear natural and justified as part of societal norms.

\section{Stereotypes in Films: A General Overview}

According to Branston and Stafford (2006), stereotyping has been a key concept in media studies, and is now perhaps too taken for granted. Many mistakes are made in using the term, which does not describe people or characters. It is easy to associate a particular character in a movie with a role that suites his personality in a movie. People find it difficult to distinguish between reality and fiction. A character in a horror movie stands the chance of suffering societal rejection as a result of a brutal role he/she has played in a movie.

In an empirical study, Smith (2008: 12) was concerned that "females take up half the space in society, yet, especially in films aimed at children, they appear much less frequently than do males. Nevertheless, when they do make it onto the silver or small screen, their portrayals can 
undermine their presence by being "hyper-attractive" or "hypersexual" and/or passive." In trying to address this concern, Haralambos traced the genesis of gender stereotype representation to a verse in the Holy Bible (Genesis 3: 16) where God said: "I will greatly multiply thy sorrow and thy conception; in sorrow thou shalt bring forth children and thy desire shall be to thy husband and he shall rule over thee." The following assumptions can be drawn from the quote above:

1. Women produce children.

2. Women are mothers and wives.

3. Women do the cooking, cleaning, sewing and washing.

4. They take care of men and are subordinate to male authority.

5. They are largely excluded from high status occupations and from positions of power.

Downing and Husband (2005) quoted Winant (1994) as saying that stereotype representation of gender and their likes are essentially metaphors for institutionalized social relationships that combine processes of exploitation and domination, on the one hand, with processes of subjection and representation, that is, with struggles over meaning and identity, on the other. The authors are of the opinion that those responsible for gender stereotypes will first of all rely on a strong universal statement to establishes the reason for such representation. Going by this statement, it is obvious that the biblical verse quoted earlier will form the basis for misinterpretation resulting in justifying female stereotype representation in society.

The mass media mirrors the society and since film is a mass medium, it is not an exception. Dutt (2014) aligned with this by saying: "Many cultural constructions, societal norms, fantasies and historical moments are conveyed and understood through films." A clear indication that considering the importance of women in society, how they are represented in films should be taken seriously. According to Kord (2005), "films show us what we are, what we were, and what we could, should, or (do not) want to be. When at their best, they give birth to new visions of female 
strength and freedom. At their worst, they ridicule, denigrate, deny what real women have long achieved, and replaced it with spectres from the past."

Kuhn (1982) believes that women are increasingly used as visual accessories. Changes in film images have not always paralleled actual changes in society. Particularly with regard to the depiction of women, we can see how social values mediate between changes in the real world, the images that become available on television, and viewers' choices of film images to watch. Women in films of the 1930s and 1940s seldom ventured outside of their socially prescribed roles as sweethearts, wives or mothers to the male hero. By providing a romantic interest for the hero, the woman served the function traditionally assigned to her gender (particularly in film) while allowing the male character to play out his own pre-ordained role (Stewart and Kowalztke, 2007: 40).

According to Dutt (2014), “today's on-screen women need to have it all, and then some; 'the gorgeous Amazonian buttkicker' with the great ass snug in super heroic spandex." Pevere (2003) qualified this class of women as the "empowered" woman of corporate consumer society. To Ross (2006), women must be strong, aggressive, but still beautiful and sexy. Regrettably, this so-called tough woman is a 'testament to a still male-dominant society's own contradictory responses to women's demands for equal treatment. Dutt (2014) points out that a duality is exhibited in most female characterizations in Hollywood (respect and rebellion, beauty and brains, power and submission, sexuality and timidity, and so on.) so that all viewers relate to and enjoy something. This position has been shared by many scholars around the world on the same subject matter and the Nigerian film industry is not an exception. 


\section{Stereotype Representation of Women in Nigerian Movies}

The Nigerian film industry gained global recognition in the 2000s. It is one of the fastest growing film industries in the world. According to Adeshokan (2006), while reacting to reviews made on the Nigerian movie industry, "Very few of the commentaries bother to describe the films in any intelligible manner or even historicize them. Mere familiarity with the Nollywood label does not prepare anyone for films made in several Nigerian languages, nor does it draw attention to the vast use of video and digital technologies as markers of new social identities outside of filmmaking." Nevertheless, Nollywood (as the industry is called) films have continued to enjoy patronage especially around the continent of Africa. This popularity has been further encouraged by the availability of different cable and satellite television platforms within the continent who have dedicated channels for Nollywood films. Adjudged as the third largest film industry in the world (Opeyemi, 2008), Nollywood has transformed over time from crude to professional filmmaking with a good number of its actors, directors, actors, producers and screenwriters now going into partnership with international movie producers.

There is no disputing the fact that the media mirror's society. This therefore means that representation in Nigerian films is a subtle suggestion to the world that this is exactly what is happening in Nigeria. Barber (1987) said "The views that ordinary people express may be false consciousness, but they are also their consciousness . . . conservative and misogynist, and sometimes frivolous ... the people's arts represent what people do in fact think, believe, and aspire to."

According to Bryce (2012) "Nollywood films, notably, care little for realism, beyond a love of surface: porticoed mansions, luxurious furnishings, gorgeous clothes, expensive cars, the proliferating signs of wealth by which they signal power and its attributes along with bodies, rich, 
intact, and beautiful or poor, diseased, and abject." There is no doubt that the industry has tried in its own way to project Nigeria in good light. Though the women have made a name for themselves in the Nigerian film industry, there have been lamentations from media scholars over the stereotype representation of women in Nigerian films. Okome (1997) as quoted by Shaka and Uchendu (2012) lamented that since the release of Living in Bondage the thematic preferences of Nollywood movies are based on the notions of inherited stereotyping of women perpetuated by patriarchy.

Adeshokan (2006) admits that Nigeria is suffering from an image problem in the international community. The more reason why film makers should encourage positive stereotypes of women in films. This will help in boosting the image problem that Adeshokan (2006) was talking about. Having said this, scholars, especially feminists are of the opinion that the film industry has continued to adopt the patriarchal Nigerian society where the woman must be a submissive housewife to her husband, irrespective of whatever way he chooses to behave in society. Some noticeable stereotype representation of women in Nigerian films are as described below:

\section{The femme fatale}

This deadly woman uses her sexuality to destroy men in order to further her own ends; it is not usually love she is after. This is represented in many films like Aki the Blind where Ebube Nwogwu, the new wife of Amaechi Muonaguor uses her power as a woman to manipulate the rich man. Despite belonging to a cult, he obeyed every instructions she gave him. Similarly, in the Three Generals, Patience Ozokwor, in one of her roles as General has a set of girls that she sends to men to extract information and rob them. 


\section{The girl next door}

This is the stereotype of the sweet and trusting young woman who is portrayed as the ideal marriage prospect. This is the dream of every man. After messing around with several women, every mother in Nigerian films will tell her son to marry a 'decent' girl, preferably a virgin. Hence the man will go about searching for that 'decent' girl. In the Igbo film Nwa Mary, Edu Brazil that had messed around with another girl comes after Rachael Okonkwo, a religious girl that has preserved herself according to the dictates of the Bible. Sometimes, this search for a decent girl by mothers for their sons usually leads them into getting girls who will pretend to be good girls. As it is in Native Fowl where Clems Ohamezie's mother was preserving the wayward Nuella Njubigbo (who pretended to be a virgin) for her son.

\section{Gold diggers and trophy wives}

These stereotypes perpetuate the myth that women marry for money and are reliant on men to support them. This can be seen in films like The Prince and the Slave where Patience Ozokwor in her bid to ensure that her daughter got married to the prince out schemed Eve Essin who the prince was in love with. This is a common representation in many films that involve a prince or a son of a wealthy man looking for a wife to settle down with. The gold diggers can come in two forms, sometimes it is the greedy mother that will force the daughter in to marrying the rich man as the case mentioned above in other times, it is the girl that will maneuver her way into the man's life using whatever means possible. An example is in the movie, Prince Apart where Chacha Eke played into the hands of Uche Odoputa, the younger brother of her fiancé, Kenneth Okonkwo, just because she thought the former will be crowned king. 


\section{The career woman}

Since the 1980s the stereotype of the career woman has become increasingly common. She is successful but she can also be ruthless. In most cases, despite her level of success, a man will be needed to help in taking care of her emotional problems. This can be seen in movies like Anita starring Jackie Appiah, a successful lawyer and a faithful wife.

\section{The housewife}

This is the most favored stereotype in Nigerian films, the housewife exists only to support her husband and children. In line with the patriarchal nature of the society, a good wife by Nigerian standards is one that is totally submissive to the husband in his struggles in life. This spans beyond just taking care of the house or the kitchen as many men will say a woman's place is in the kitchen. Out of the little she gets from the husband, she engages in petty trading to support the household. In most cases, even in her struggles, it is common to see the husband accusing her of engaging in prostitution to get money. Even with the accusations, the husband takes the money she has saved for the upkeep of the family to go after liquor and other women. In Baby Dance With Tears starring Mercy Johnson, she had to marry a man that she felt she was indebted to because he did her a favor. She was so supportive in the man's business that even when she was pregnant, she was compelled to go out and dance until she had a miscarriage.

\section{The object of barter}

This represents women as objects that can be used for exchange by their parents when indebted to a rich man and cannot pay. This is seen in the Yoruba movie, Labake Omo Oko where Faithia Balogun had to be married to a man against her wish just because her father is indebted to the man. In some cases, it is as a result of the parent's greed for material things that they will 
compel the daughter to marry the man she does not like. An example is the Igbo film Nne Ifeadigo where Patience Ozokwor pushed her daughter, Nuella Njudigbo to marry a drug baron.

\section{The object of ritual}

This stereotype portrays women as the best options for rituals by rich men and even the gods. Young girls, virgins in most cases are usually the targets. If virgins are not targeted, it will be either the university campus girls or any woman the rich man can lure in to his trap. In the film, Agafe apart from the detailed sexual content of some scenes, the character Frank Artus spent money on young girls and used them as sacrificial lambs. Similarly, the movie, Seven Rivers had scenes of a rich man who deceived girls to come to his apartment where they are used for sacrifice.

\section{Objects of sexploitation}

This stereotype portrays women as easy targets for sexual exploitation by men. In most cases, it will be the boss that will be exploiting the house girl. As in Baby Dance with Tears where Mercy Johnson was constantly harassed by her aunt's husband. Her resistance put her in the bad books of her aunt. In Labake Omo Oko, Faithia Balogun while escaping from her matrimonial home as a result of maltreatment from her cowives, sought refuge in the house of a family acquaintance who in the middle of the night raped her and when the wife of the man eventually caught them, Faithia was asked to leave.

\section{The witch}

This stereotype portrays women especially old women as witches whose mission is to deny the progress of young men and women. In Twins in Sorrow, Patience Ozokwo hated her son Clems 
Ohamezie so much that she kept trying to kill him until she finally succeeded, after reducing him to a pauper. This is one out many examples of Nigerian films.

\section{Prostitutes}

This stereotype is common among young city girls trying to earn a living, especially campus girls. It suggests that the easy way for a woman to hustle in the city for better lifestyle is either to be sleeping around with different men or to serve as a mistress to a man who will service her needs even when she knows he is married. This is well expressed in films like Blackberry Babes. An indication that girls can use their bodies in exchange for money.

\section{Second choice}

This stereotype suggests that the girl child is less important in society when compared to the male child. At the point of conception, the family of the husband will be expecting the wife to give birth to a male. It makes it look as if the power to give birth to male children lies with the woman alone. It suggests that giving birth to girls is not a good option if a woman must be loved by her in-laws. In mother In-law, Camila Mberekpe was maltreating her son's wife for not giving him a male child. In her desperation to get a male grandson, she had to marry a girl from the village for her son without his knowledge. This impression has come to affect the psyche of many Nigerian women in real life to the extent that the moment they conceive, they will be praying for a baby boy

\section{Husband killer}

This stereotype portrays women especially wives of rich men as those who will eliminate the husbands just to inherit his wealth. It is common in Nigerian films to see the wife being accused of killing her husband. In most cases, the woman is made to take some oaths and perform some 
rituals that are harmful to her health. For example, in Widow's Fate, Queen Nwokoye was accused of killing her husband and for that reason subjected to several wicked treatment engineered by her brother in law, Chiwetalu Agu, who is indeed the culprit.

Bryce (2012) saw a potential danger in this trend. "Nollywood, by constantly returning us to traditional notions of the good, submissive wife and nurturing mother, does not represent the reality of women's position in Nigeria and the manifold aspects of their self-realization."

\section{Conclusion}

Although representation has been a subject of media studies for a very long time, Stewart and Kowaltzke (2007) posited that "After nearly 40 years of modern feminism, more than 30 per cent of advertising still portrays women as slim, blond bimbos less than 30 years old." Within the Nigerian society, it is a major area of debate as various groups who feel misrepresented come up with forums to find ways of changing the situation. Bryce (2012) explains one of such forums. " In 2010, a two-day forum, 'Nollywood and the Dynamics of Representation,' took place in Lagos, calling on participants to correct certain negative impressions created in our movies on the womenfolk who, it was claimed, come as wicked, manipulative, loose in morals, diabolic, and inferior to the men." After this forum, several such forums have taken place in different dimensions.

In the de facto taking over of responsibility for national identity by cinema since the $1990 \mathrm{~s}$, what is at stake is as much economic as cultural, as much about material power as about representation. This is because cinema is both an industry implicated in wealth-generation and a cultural medium that reaches deep into the domestic space of consumers for whom an elite literature is inaccessible. As a result, questions arise about the role and status of Nollywood as a 
"national" cinema. (Bryce, 2012: 74). A devotion of quality time to research on the cultures in the country and a reflection of the present trend existing in the country will help in a more balanced approach to representation of women in Nigerian films. Stereotypes can be both positive and negative. It is time Nigerian filmmakers started looking the way of positive stereotype representation of Nigerian women in films, instead of continuous inundation of the market with negative stereotype representation.

\section{Recommendations}

The representation of women is an area that needs to be further researched upon. Filmmakers must try to reflect the current situation in society while bearing in mind the fact that society is dynamic. So many positive things about women have been going on around the country. These things are capable of bringing good scripts that will portray women in good light. There is no denying the fact that such issues reflected in Nigerian films like prostitution, gold diggers husband killers are truly things that happen in society. But it should be noted that the more the project these things on a daily basis, the more members of the audience will see them as the right thing to do, thereby increasing the chances of their flourishing. Good research will help in taking the minds of the audience away from such negative stereotypes and focus them on other issues happening in the society.

Women should be involved in film production as directors and producers instead of allowing men to dominate the industry. Their own side of the story will always give the type of representation they want. This trend is beginning to happen as many female producers and directors are beginning to be involved in the Nollywood project. People like: Funke Akindele, Stephanie Okereke Linus, Rita Dominic, Uche Jombo among others have worked on award winning movies as producers and directors. Having more of them in the industry will turn negative 
representation into positive ones that will make the society to treat the women as equals and sisters in progress.

\section{BIBLIOGRAPHY}

Adeshokan, A (2006). 'Issues in the New Nigerian Cinema.' Black Camera. Vol 21. No.1: 6

Aina, I. Olabisi (1998) "Women, culture and Society" in Amadu Sesay and Adetanwa Odebiyi (eds). Nigerian Women in Society and Development. Ibadan: Dokun Publishing House.

Allanana, M. G. (2013). Patriarchy and Gender Inequality in Nigeria: The Way Forward. European Scientific Journal. Vol 9, 17: 115-144.

Amobi, I (2013). Portrayal and Participation of Women in Nigerian Media.

Asiyanbola, A. R. (2005). Patriarchy, Male Dominance, the Role of Women Empowerment in Nigeria. Paper submitted for presentation as poster at the International Union for the Scientific Study of Population (IUSSP/UIESP) XXV International Population Conference Tours, France.

Barber, K.(1987). "Popular Arts in Africa.” African Studies Review 30. 3: 1-78.

Blench, R (2003). Position Paper: The Dimensions of Ethnicity, Language and Culture in Nigeria. Cambridge: DFID.

Branston, G. And Stafford Roy (2006). The Media Student's Handbook. London: Routledge.

Bryce, J (2012). 'Signs of Feminity, Symptoms of Malaise: Contextualising Figuration of Woman in Nollywood.' Research in African Literature. Vol 43 No.4: 71-87.

Buckingham, D. (2003). Media Education: Literacy, Learning and Contemporary Culture. London: Polity.

Cheu, J (2013). Diversity in Disney Films: Critical Essays on Race, Ethnicity, Gender, Sexuality and Disability. Jafferson: McFarland and co. 
Cottle, S (2000). Ethnic Minorities and the Media. Buckingham: Open University Press.

Downing, J.D.H and Husband, C (2005). Representing Race: Racism, Ethnicities and Media. London: Sage.

Fenton, S. (1999). Ethnicity: Racism, Class and Culture. Basingstoke: MacMillan

Gerbner, G., Gross, L., Morgan, M., \& Signorielli, N. (1986). Living with television: The dynamics of the cultivation process. In Bryant, J. \& Zillmann, D, Perspectives on Media Effects: 17-40. Hillsdale, NJ: Lawrence Erlbaum.

Goodwill, M., Good, J. and Godfrey, W. (2007). Crash Cinema: representation in film. Newcastle: Cambridge scholars publishing.

Hall, S. (1997). Representation: Cultural Representations and Signifying Practices. London: Sage.

Hall, S. (2005). 'Encoding and Decoding in Television Discourse' in Channelling Blackness: Studies in Television and Race in America. New York: Oxford University Press.

Haralambos, M, Holborn, M and Heald, M (2004). Sociology: Themes and Perspectives. London: Harper-Collins.

Humm, M. (1992). Feminism: A Reader. London: Harverster Wheatsheaf.

Jordan, W.D (1969). White Over Black. Harmondsworth: Penguin.

McDugall, J. (2012). Media Studies: The Basics. London: Routledge

McQuail, D. (2010). McQuail's Theory of Mass Communication. London: Sage.

Stewart, C and Kowalztke, A. (2007). Media: New Ways and Meanings. Sidney: Jacaranda.

Opeyemi, F.K (2008). 'Nollywood Portrayal of the Nigerian Society.' International Journal of Communication. No.9: 286.

Richardson, J (1990). 'Race' in Haralambos, M. Developments in Sociology vol.6. Ormskiru: Causeway 
Ross, K., and Byerly, C. (2006). Women and Media: A Critical Introduction. Malden, MA: Blackwell.

Kord, S., and Krimmer, E. (2005). Hollywood Divas, Indie Queens, and TV Heroines: Contemporary Screen Images of Women. Lanham: Rowman \& Littlefield.

Kuhn, A. (1982). Women's Pictures: Feminism and Cinema. London: Routledge \& K. Paul.

Pevere, Geoff (2003). 'Bumming-down Hollywood Women.' The Toronto Star 18 July 2003: 13.

Smith, L. S. (2008). 'Gender Stereotypes: An Analysis of Popular Film and Television.'

Presented at The Geena Davis Institute on Gender in Media Conference. Retrieved on $5^{\text {th }}$ April, 2016: www.thegeenadavisinstitute.org: 12-23

Steiner, L. (2014). Feminist Media Theory, in The Handbook of Media and Mass Communication Theory (eds Fortner, R. S. and Fackler, P. M.), John Wiley \& Sons. 